\title{
THE EFFECT OF MEGA-PROJECTS ON SUSTAINABLE URBAN DEVELOPMENT FROM THE PERSPECTIVE OF CITIZENS (CASE STUDY: PADIDEH TOURISM COMPLEX OF SHANDIZ)
}

\author{
Zahra Anabestani \\ PhD Student of Geography and Urban Planning, Science and Research Branch, Islamic Azad University \\ Tehran, Iran \\ Rahim Sarvar \\ Prof, Geography Department, Science and Research Branch, Islamic Azad University Tehran, Iran \\ sarvarh83@gmail.com \\ Mas'oud Mahdavi Hajiluie \\ Prof, Geography Department Science and Research Branch, Islamic Azad University Tehran, Iran
}

\begin{abstract}
Presence of a metropolitan project (megaproject) at a national scale would bring a considerable transformation in different scales of life of citizens in an urban settlement. This paper has been conducted to assess the effect of presence and activity of tourism complex of Padideh on sustainable development in Shandiz during 2009-2015 from the perspective of citizens. Methodology of this study in terms of objective is applied and is analytical-descriptive in terms of method; data collection method has been library and survey (questionnaire) method and data analysis has been conducted through descriptive statistics (mean, standard deviation) and inferential statistics (one sample and paired t-test, analysis of gray relational rating and structural equation). Statistical population of this study includes families living in Shandiz City with 5110 households. Statistical population of this study includes households of city of Shandiz with 5110 households and 17378 people based on the census of 2011; sample size of this study is obtained to 236 households based on Chochran formula. The obtained results of this study indicates that effects of presence and activities of tourism complex of Padideh in city of Shandiz with statistical value of 24/15 has had the most effect on economic aspect during studied time interval and social motivation, price of land and housing and profitability among indices have been more effected by this megaproject from the perspective of citizens. There are some recommendations in accordance with the findings of this study including strategies of urban managers in relation with changes in future market of land and housing, preparing some fields to attract tourists, paying attention to social conflicts and preventing them from occurrence, and preparing infrastructures etc.
\end{abstract}

Keywords: tourism complex of Padideh, economic aspect, social motivations, physical aspect, city of Shandiz

\section{INTRODUCTION}

\section{STATEMENT OF THE PROBLEM}

The purpose of urban megaprojects is to meet the needs to positive changes of different aspects of city during a short time while experiences of urban megaprojects in developed and developing countries have demonstrated another situation. Complicated and long-term megaprojects have faced economic fluctuations as well as shortcomings of forecasting methods, cost estimations, results of implemented urban megaprojects and effect of political conditions as challenges of urban megaprojects during planning, implementation and exploitation (Orueta \& Fainstein, 2008, P. 763). Urban megaprojects can effect on many social groups in accordance with their broad effective domain. There are some negative and positive social effects of implementation of urban megaprojects including demographic migrations and movements in cities due, establishment of new 
native and non-native groups in context of city, change in former identity and character of context, creation of an alien physical environment for residents and workers, effect on type and quality of job in city or false promises about social reforms, settlement of social crisis and increase in job opportunities and low-cost housing (Jia et al, 2011, P. 817, Storey \& Hamilton, 2004, P. 282 \& Ponzini, 2011, P. 253).

Sustainable urban development has five purposes including a sustainable urban future European cities based on the minimum use of space and natural resources, developing efficient administration of urban flows, protecting health of urban population, providing equal access to resources and services and preserving social and cultural diversity (Kanaroglou, 2009, P. 32). Proponents of urban development has tried to pay attention to economic, social, environmental and physical aspects of projects with emphasize on rational projects in order to reach an ideal city through interaction between mentioned aspects. Hence, the importance of sustainability in purposes of city development has brought an extensive domain of social, economic, cultural, ecologic, and physical needs in order to achieve the considered sustainability that is defined in frame of urban sustainable indices (Poorjafar et al, 2011, P. 25).

City of Shandiz with population over $17 / 000$ people and area of 1414 hectares is located at 15 kilometers distance far from Mashhad in Iran. This city has been recognized as one of attractive summer areas for citizens living in the city of Mashhad in regional dimension and for pilgrims of Imam Reza (eighth Shi'a Imam) in national dimension. There have been major investments in urban megaprojects such as tourism complex of Padideh in city of Shadiz so that the consequences of these investments have effected on the urban structure of Shandiz before and after exploitation from megaprojects. The mentioned complex has been established in a space more than 50 hectares in which, there are hotels, shopping and entertainment center, apartments, water park, etc. with an area more than 1175 hectares (International Development Company of tourism industry of Padideh of Shandiz, 2015).

The tourism complex of Padideh is considered as an urban megaproject at local, regional and national levels due to its features including complexity, large scale, attractive for citizens at national, regional and local levels, high costs of establishment and exploitation, attracting investments of citizens out of Shandiz city and debatable issues of project. Presence of megaprojects in small scale of a city like Shandiz have some consequences so that such project can promote the position of city at local, regional and even national levels; on the other hand, there are various challenges for sustainable development in this urban settlement and even in mega city of Mashhad if the project is not succeeding or its consequences are not predicted. Therefore, it would be essential to study the urban megaproject of Padideh in city of Shandiz and its consequences. Accordingly, the main question of this study is that what are the short-term positive and negative effects of tourism complex of Padideh of Shandiz on urban sustainable development in at social, economic, physical-spatial and environmental dimensions in this region of Iran from the perspective of citizens?

\section{RESEARCH BACKGROUND}

There has not been any conducted study in field of urban megaprojects and their role in urban sustainable development in Iran. There are few published papers in field of megaprojects mentioned as follows:

Pahlavan has assessed the effect of establishment of urban megaproject of Almas Shargh (East Diamond) on development of local communities in three districts of Toos, Karizak and Esmaeel Abad in Mashhad, Iran. The obtained results of this study indicated that implementation of a developed project not only could not improve economic and social dimensions but also created some problems such as security reduction and movement of residents. Annabestani et al (2014) indicated that socio-economic factors of activities of tourism complex of Padideh in Shandiz have had the most effect on changes in market of land and housing in accordance with statistical value of $36 \%$. 
In addition, the studies conducted by Annabestani et al (2013) in field of effect of Tourism Complex of Padideh on urban development of Shandiz indicates that among variables related to the presence of Tourism Complex of Padideh, the most importance coefficient has been related to economic consequences with value of $45 / 5 \%$ and the lowest importance coefficient has been related to environmental effects of Padideh in Shandiz with value of $8 / 2 \%$ in accordance with obtained results from experts survey. Moreover, another conducted studies by Annabestani and Annabestani (2013) in field of role of Passive Defense in location of urban megaprojects (Case study: Tourism Complex of Padideh of Shandiz) indicates that among existed eight elements in dream city of Padideh, five star hotel has had the vital role and other centers are classified in sensitive goals; in accordance with obtained results from Carver Matrix, only location selecting and resistance of building among eleven elements of Passive Defense have been considered in location of this urban project.

Finally, the obtained results from relevant studies to megaprojects indicate that the main purposes of establishment of these megaprojects include creating required spaces for settlement, tourism and sport. On the other hand, creation of such projects has brought special social, economic and environmental consequences for urban areas while the physical effects have been satisfying. All relevant studies (described in table 1) have emphasized on created social challenges due to the establishment of megaprojects.

Table 1. Research background of foreign studies of megaprojects

\begin{tabular}{|c|c|l|}
\hline Author & Title & \multicolumn{1}{|c|}{ Results } \\
\hline $\begin{array}{c}\text { Priemus, et } \\
\text { al. 2008 }\end{array}$ & $\begin{array}{c}\text { Planning and design of } \\
\text { infrastructural } \\
\text { megaprojects }\end{array}$ & $\begin{array}{l}\text { The physical effects of infrastructural megaprojects might } \\
\text { be satisfying while environmental effects, economic } \\
\text { results and technical predictions of projects could be } \\
\text { insufficient. }\end{array}$ \\
\hline $\begin{array}{c}\text { Douglass, } \\
2005\end{array}$ & $\begin{array}{c}\text { Globalization of } \\
\text { megaprojects and } \\
\text { environment and urban } \\
\text { structure of Jakarta }\end{array}$ & $\begin{array}{l}\text { Great tendency toward megaprojects would seriously lead } \\
\text { to expansion and reconstruction of urban space through } \\
\text { an inappropriate way based on the environmental view. }\end{array}$ \\
\hline $\begin{array}{c}\text { Ponzini, } \\
2011\end{array}$ & $\begin{array}{c}\text { Megaprojects and star } \\
\text { architectural projects in } \\
\text { absence of democratic } \\
\text { policies }\end{array}$ & $\begin{array}{l}\text { There is debate on development method of Abu Dhabi } \\
\text { through megaprojects and non-indigenous architecture } \\
\text { and it is essential to consider social context of projects. }\end{array}$ \\
\hline Jia, et al. & $\begin{array}{c}\text { Study of megaprojects } \\
\text { from the view of social } \\
\text { conflict theory }\end{array}$ & $\begin{array}{l}\text { This study has emphasized on the relationship between } \\
\text { megaprojects and globalization as well as the interaction } \\
\text { between social context and megaprojects. }\end{array}$ \\
\hline $\begin{array}{c}\text { Abdulaal, } \\
2012\end{array}$ & $\begin{array}{c}\text { Urban large-scale } \\
\text { development as the } \\
\text { driving force of land } \\
\text { development in Jeddah }\end{array}$ & $\begin{array}{l}\text { Large-scale projects are not able to resolve urban } \\
\text { challenges; therefore, megaprojects should complete each } \\
\text { other and municipality should control sustainability and } \\
\text { coordination of megaprojects based on urban landscape. }\end{array}$ \\
\hline $\begin{array}{c}\text { Briemus, \& } \\
\text { Wee, 2013 }\end{array}$ & $\begin{array}{c}\text { Megaprojects, urbanism } \\
\text { and social advantages }\end{array}$ & $\begin{array}{l}\text { There is a challenge among social theories in comparison } \\
\text { of megaprojects of Vancouver, Montreal and Los } \\
\text { Angeles. }\end{array}$ \\
\hline & $\begin{array}{l}\text { Megaprojects include large projects and political show in } \\
\text { terms of decision-making and their infrastructures in } \\
\text { which, public investment exist. }\end{array}$ \\
\hline
\end{tabular}


The Turkish Online Journal of Design, Art and Communication - TOJDAC July 2016 Special Edition

\begin{tabular}{|c|c|l|}
\hline $\begin{array}{c}\text { Divandari, } \\
\text { et al, 2014 }\end{array}$ & $\begin{array}{c}\text { retrieval of a commercial } \\
\text { model for multiple } \\
\text { megaprojects }\end{array}$ & $\begin{array}{l}\text { The main factor of establishment of megaprojects is seen } \\
\text { within some cases including entertainment, housing, } \\
\text { tourism and sport. }\end{array}$ \\
\hline $\begin{array}{c}\text { Mok, et al. } \\
2014\end{array}$ & $\begin{array}{c}\text { Studies of beneficiaries' } \\
\text { management in } \\
\text { establishment of } \\
\text { megaprojects }\end{array}$ & $\begin{array}{l}\text { It would be essential to recognize the effect of national } \\
\text { culture in management methods of beneficiaries in scope } \\
\text { of megaprojects. Therefore, method of social networks } \\
\text { should be applied to manage the relationships between } \\
\text { beneficiaries within these projects. }\end{array}$ \\
\hline $\begin{array}{c}\text { Hwang, } \\
2014\end{array}$ & $\begin{array}{c}\text { Megaprojects of urban } \\
\text { index beyond the global } \\
\text { convergence }\end{array}$ & $\begin{array}{l}\text { Formation process of an urban megaproject in Seoul is a } \\
\text { result of complicated and active political fluctuations among } \\
\text { various actors at different scales within a limited area. }\end{array}$ \\
\hline $\begin{array}{c}\text { Boano, et al. } \\
2011\end{array}$ & $\begin{array}{c}\text { Forefront of competition } \\
\text { between urban } \\
\text { megaprojects and large } \\
\text { resistance }\end{array}$ & $\begin{array}{l}\text { This paper has analyzed a new conceptual expression of } \\
\text { competitive urbanism in which, there is a struggle between } \\
\text { inclusive development processes and political pressure in } \\
\text { the upper market toward activity at global level. }\end{array}$ \\
\hline $\begin{array}{c}\text { Follmann, } \\
2014\end{array}$ & $\begin{array}{c}\text { Urban megaprojects, a } \\
\text { global perspective }\end{array}$ & $\begin{array}{l}\text { The established urban megaprojects in areas of rivers has } \\
\text { caused to an informal urban separation. }\end{array}$ \\
\hline
\end{tabular}

\section{THEORETICAL LITERATURE}

\section{URBAN MEGAPROJECTS}

The large-scale infrastructural, commercial and service projects with high costs and extensive effect on urban performance are called urban megaprojects. Urban megaprojects in terms of nature, use, performance and effective scale in city include various ranges of international service and commercial centers, infrastructural and communicational megaprojects like urban subway, technological or entertainment towns, important urban projects with distinguished architectural style in city designed by famous international designers and architectures and reconstruction and renovation projects in large scale. Urban megaprojects are called megaprojects because they can make extensive, long-term or important changes in identity, socio-economic structure, role and performance of the city (Altshuler \& Luberoff, 2003, P. 19).

Megaprojects have some characteristics including enlargement, attractiveness, costly, controversial, complexity and control (Flyvbjerg et al, 2003, P. 4). Megaprojects are common methods of today urbanism also are attractive because they can redefine the city and promote the position of city at global level as well as increasing services, facilities and incomes. According to evidences, a new era of megaprojects has emerged all around the world (Douglass, 2005, P. 2). Megaprojects usually enter to urban developing projects with two different approaches including projects in large scale of construction with high symbolic importance (like construction of a special museum) and the larger projects with complicated subjects (like mixed residential complex, transport facilities, etc.) (Orueta \& Fainstein, 2008, P. 762).

Different theorists such as Jia et al (2011), Storey \& Hamilton (2004) and Ponzini (2011) in scope of urban policy-making and planning have assessed positive and negative social effects of urban megaprojects on city and citizens. According to these theorists, negative effects of these projects include social injustice, migration of resident population, elimination of identity and character of urban context, social isolation of some groups, and economic benefits for few investors, failure to meet the need for housing and employment of low-income groups, public persistence etc. Urban megaprojects can be applied as a tool to meet the demands of citizens, to provide required services and infrastructures for city and to meet required urban capitation and these projects can also be used as a tool to change the situation of city in regional and international ranking system in order to be known at trans-regional and global levels. In fact, pubic capital management in order to invest in 
megaprojects is the simplest method of urban management to make a balance between costs of required services and facilities at local scale and paying attention toward driving forces of industry, business and service sectors to compete at beyond urban and regional levels.

\section{SUSTAINABLE URBAN DEVELOPMENT}

Sustainable development is a trend to improve economic, social, cultural and technological conditions within a social justice in order not to pollute ecosystem and destruct natural resources (Azizi, 2001, P. 22). Sustainable urban development is a form of current development guaranteeing continuous development of cities and urban communities of future generation (Hall, 1993, P. 22). Attitude of sustainable development is based on this idea that technology is not able to compensate any kind of natural resource reduction and natural capital is like a human-made capital; in this regard, the UN supports conceptual view of sustainable development providing appropriate cultural fields to access sustainable development through training people. Therefore, a sustainable urban development model should be adaptable with social, economic and cultural changes of a society. Since population is the main element of sustainability, the effect of this element on economic, social and environmental factors transforming a city to an integrated system should be evaluated (Ghrakhloo \& Hosseini, 2006, Pp. 161-162).

According to the goals of sustainable development and sustainability dimensions, some important factors of sustainable development at local, regional, national or even international are required to be mentioned; these factors include paying attention to present and future generations and meeting their needs, improving social and cultural conditions, protecting sustainable environmental resources, paying attention to social, economic, cultural and physical aspects of urban and rural biological complexes as sustainable urbanization and sustainable rural development and healthy environmental justice (Taghvaee \& Safarabadi, 2013, Pp. 7-8). Theory of sustainable urban development is a result obtained from discussions of proponents of environment about environmental issues especially urban environment presented by the theory of "sustainable development" to protect environmental sources. Sustainable urban development requires identification of environmental limitations for human activities in relation with cities and adaptation of design methods with these limitations. The issue of keeping sources for present and future is presented in this theory through optimal use of land and entering waste to non-renewable sources (Blowers, 1994).

Some conditions should be provided to realize sustainable urban development in order to improve human sustainable development and social welfare of citizens. In such conditions can make social justice, design a coordinated climate with human biological environment, strengthen social correlation structures such as commitment and responsibility, strengthen social and family foundations, create public environment, establish structural discipline within an urban space to perceive urban aesthetic, benefit from urban spaces, increase citizen satisfaction and integrate visual structure of environment and urban view (Mahmoodinejad, 2006, P. 12).

According to a systemic and comprehensive view of sustainable urban development, the following dimensions should be considered:

1) Social indices: social scope is the most extensive dimension of sustainable urban development. Relevant indices to basic needs of improvement of life quality are included in this scope (Kalantari, 2006, P. 36). The mentioned indices include social security, social motivations, social justice, social identity, demographic changes, socoal participation, social awareness and life style.

2) Economic indices: these indices are provided with the aim of economic survival in farm of some items including better allocation of resources, more efficient management of resources, economy with ecological sensitivity, value-based system, fair system, emphasizing on local economy, diversity and complexity, efficiency, etc. (Skandarisani, 2007, P. 91). Economic indices of present study include job creation, income generation, investment, and land and housing prices.

3) Physical indices: relevant studies to land use, distribution method of urban activities such as residential, communicational network, health care, and education use are some data applied to prepare 
physical indices (Kalantari, 2006, P. 37). Physical indices of this study include development of physical context, development of infrastructural services, and development of housing pattern and transportation infrastructures.

4) Environmental indices: environmental indices consider destruction of environment because of urban development indicating long-term effects on region and country. Environmental destruction is due to the destruction of natural environments and agricultural lands because of development of constructions or increase in use of resources and produced waste (Kalantari, 2006, P. 37). The present study has considered environmental indices such as change in environmental landscape, environmental health and environmental hazards.

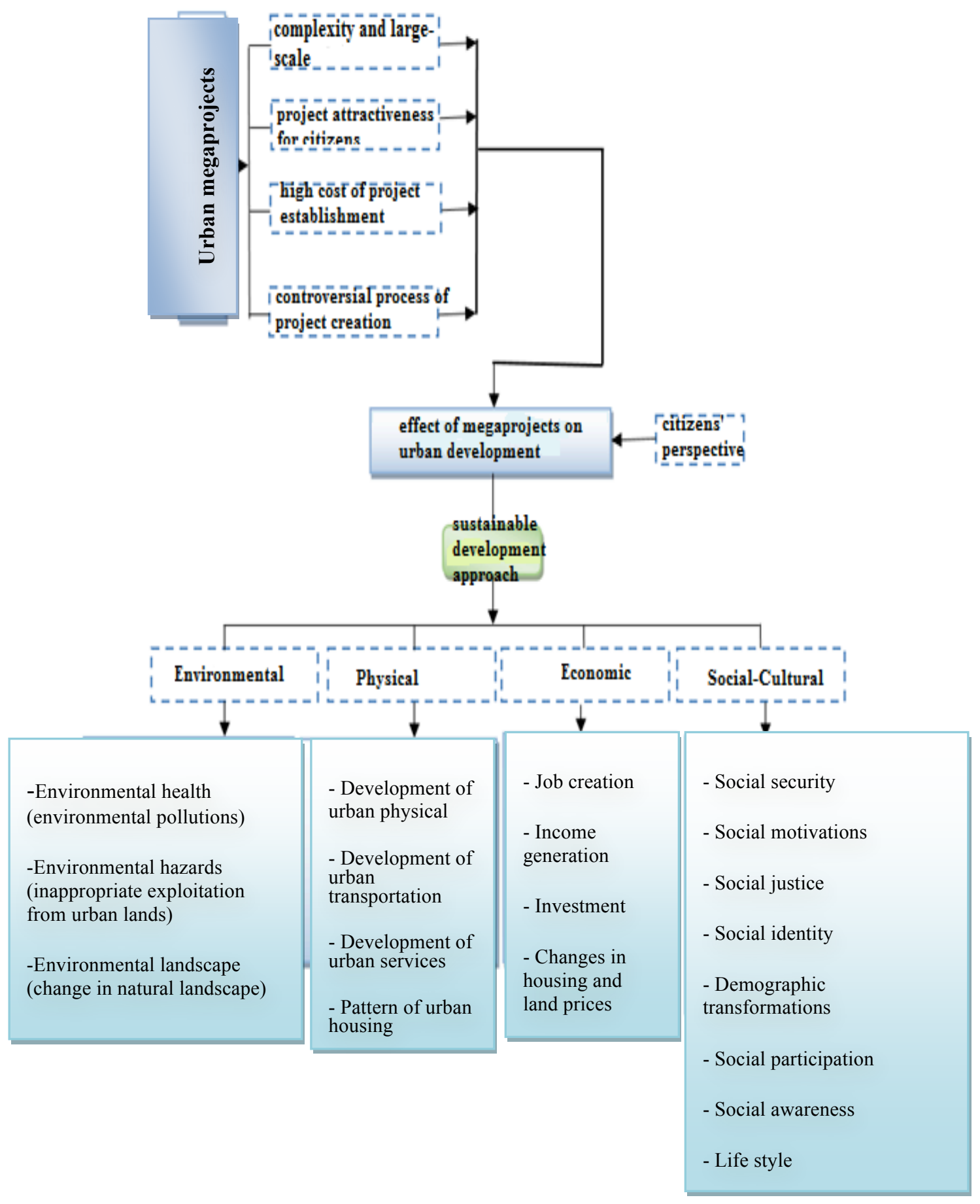

Figure 1. Conceptual model of variables of study

(Source: Research findings, 2015) 


\section{STUDY AREA}

City of Shandiz is located at 15 kilometers distance in west of Mashhad with geographic width 36 degrees and 23 minutes and longitude of 59 degrees and 17 minutes and an average elevation of 1,400 meters above sea level. Shandiz has been a place to spend leisure time for all people because of its location in northern domain of Binalood heights with temperate climate, abundant water, large gardens and spectacular natural sceneries (Governorship of Khorasan Razavi, 2015). This city with its neighboring villages had 17378 number of population in 2011. According to political divisions, the center of Shandiz is Binallod and is administrating with municipality in terms of management. (Statistical Center of Iran, 2011).

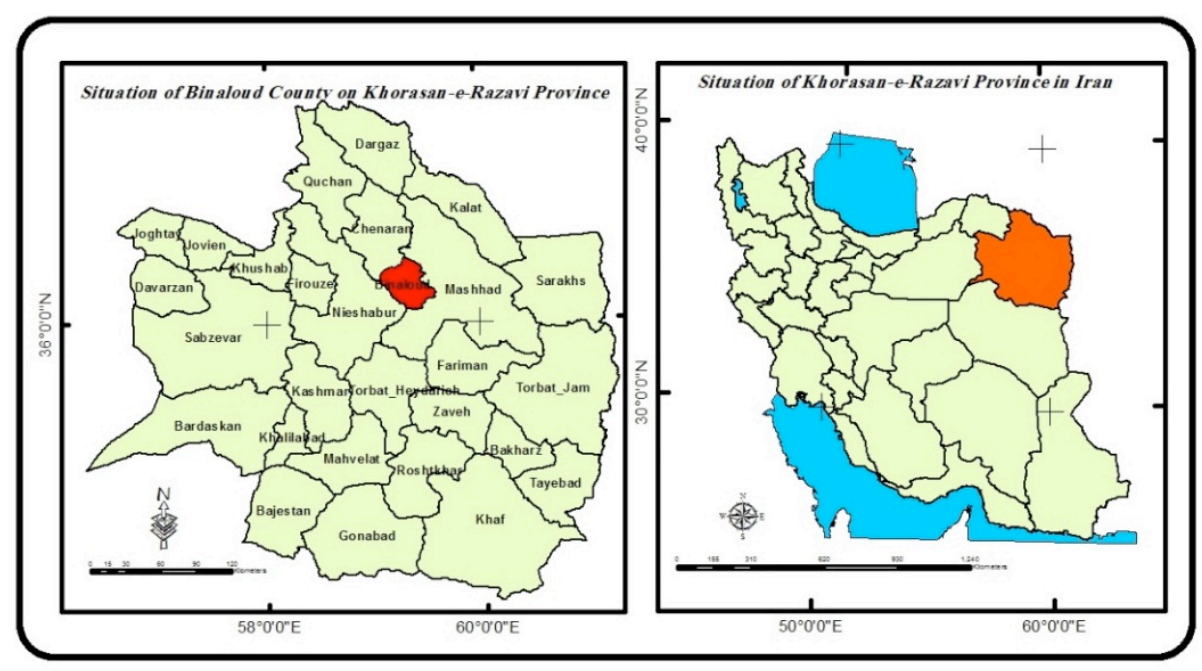

Figure 2. Situation of studied region

(Source: Research findings, 2015)

Establishment process of dream city of Padideh in Shandiz has been started in 2009 and it was supposed to be finished in 2014, but this project has been finished yet due to legal and capital problems. This complex consists of:

- $\quad$ Water park with area of 53000 square meters;

- $\quad$ Cultural complex and relevant element with area of 27000 square meters;

- $\quad$ Five-star hotel with area of 250000 square meters;

- $\quad$ Flower garden with area of 40000 square meters;

- $\quad$ Grant shopping center and entertainment with area of 560000 square meters;

- $\quad$ Administrative complex of Dream City of Padideh with area of 32000 square meters;

- $\quad$ Residential apartments with area of 183000 square meters;

- $\quad$ Indoor Amusement Park with area of 30000 square meters (International Development Company of Tourism Industry of Padideh of Shandiz, 2015).

\section{METHODOLOGY}

Methodology of this study is applied in terms of objective and is analytical-descriptive in terms of experimental method; a part of data has been collected through survey studies using questionnaire and interview and other part of required data such as theoretical and conceptual frame of study, 
documents, evidences and censuses have been collected through library studies. Statistical population of study includes households living in city of Shandiz, this city has 5110 households and 17378 number of population based on the census of 2011. Sample size of this study was obtained to 236 households in accordance with Cochran formula with probability level of 95\%. Households have been randomly chosen respecting principle of equal opportunity to select households. Accordingly, a questionnaire has been prepared to access considered results and to assess the effects of activities and presence of tourism complex of Padideh in Shandiz (because of establishment of dream city of Padideh) during 2009-2015 on sustainable urban development of Shandiz in frame of 19 determined indices related to four social, economic, physical and environmental aspects (Table 2).

Table 2. Variables and indices of sustainable urban development

(Source: Kalantari, 2006; Taghvaee \& Safarabadi, 2013; Gharakhloo \& Hosseini, 2006; research findings, 2015)

\begin{tabular}{|c|c|c|c|c|}
\hline$\underset{t}{\text { Aspec }}$ & Indices & Referrals & $\begin{array}{c}\text { Number } \\
\text { of } \\
\text { elements }\end{array}$ & $\begin{array}{c}\text { Cronbachs' } \\
\text { alpha }\end{array}$ \\
\hline \multirow{8}{*}{$\begin{array}{l}\mathscr{C} \\
0 \\
\stackrel{\Omega}{0} .\end{array}$} & $\begin{array}{c}\text { Social } \\
\text { security }\end{array}$ & $\begin{array}{l}\text { Increase in security of city of Shandiz, satisfaction } \\
\text { with social security before and after establishment of } \\
\text { Padideh and satisfaction with cultural changes, etc. }\end{array}$ & 5 & 0.779 \\
\hline & $\begin{array}{c}\text { Social } \\
\text { motivations }\end{array}$ & $\begin{array}{l}\text { Being optimistic about future of Shandiz, tendency } \\
\text { toward living in Shandiz before and after } \\
\text { establishment of Padideh, satisfaction with new } \\
\text { situation of Shndiz, etc. }\end{array}$ & 6 & 0.656 \\
\hline & Social justice & $\begin{array}{l}\text { Existence of social gap before and after Padideh, the } \\
\text { role of urban management in providing rights of } \\
\text { citizens, etc. }\end{array}$ & 6 & 0.679 \\
\hline & $\begin{array}{l}\text { Social } \\
\text { identity }\end{array}$ & $\begin{array}{l}\text { Sense of belonging to Shandiz before and after } \\
\text { Padideh, satisfaction with presence of tourists of } \\
\text { Padideh Project, satisfaction with credit of Shandiz, } \\
\text { etc. }\end{array}$ & 5 & 0.663 \\
\hline & $\begin{array}{l}\text { Demographic } \\
\text { transformatio } \\
\text { ns }\end{array}$ & $\begin{array}{l}\text { Immigration to Shandiz before and after Padideh, } \\
\text { effect of Padideh on tourists to stay in Shandiz, etc. }\end{array}$ & 5 & 0.574 \\
\hline & $\begin{array}{c}\text { Social } \\
\text { participation }\end{array}$ & $\begin{array}{l}\text { Participation level of citizens in Padideh project, } \\
\text { supervision of citizens on urban management, social } \\
\text { correlation level before and after Padideh, etc. }\end{array}$ & 4 & 0.770 \\
\hline & $\begin{array}{c}\text { Social } \\
\text { awareness }\end{array}$ & $\begin{array}{l}\text { Recognition level of Padideh project, notification } \\
\text { about activities of Padideh, presence of experts in } \\
\text { Shandiz before and after Padideh, etc. }\end{array}$ & 5 & 0.761 \\
\hline & Life style & $\begin{array}{l}\text { Effect of Padideh on life style, job and entertainment, } \\
\text { satisfaction with life style before and after Padideh, } \\
\text { etc. }\end{array}$ & 5 & 0.590 \\
\hline
\end{tabular}


The Turkish Online Journal of Design, Art and Communication - TOJDAC July 2016 Special Edition

\begin{tabular}{|c|c|c|c|c|}
\hline \multirow{4}{*}{$\begin{array}{l}\text { T. } \\
0 \\
\stackrel{0}{0} \\
\stackrel{0}{0}\end{array}$} & Job creation & $\begin{array}{l}\text { Effect of Padideh on job future, effect of Padideh on } \\
\text { reducing economic dependence of Mashhad City, } \\
\text { satisfaction with existed job opportunities before and } \\
\text { after Padideh }\end{array}$ & 9 & 0.853 \\
\hline & $\begin{array}{l}\text { Income } \\
\text { generation }\end{array}$ & $\begin{array}{l}\text { Satisfaction with income level before and after } \\
\text { Padideh, effect of Padideh on business activities, etc. }\end{array}$ & 4 & 0.717 \\
\hline & investment & $\begin{array}{l}\text { Effect of Padide on changes in investment directions, } \\
\text { investment of non-native people before and after } \\
\text { Padideh, etc. }\end{array}$ & 6 & 0.662 \\
\hline & $\begin{array}{l}\text { Land and } \\
\text { housing } \\
\text { prices }\end{array}$ & $\begin{array}{l}\text { Increase in price of land and housing befor and after } \\
\text { Padideh, effect of Padideh on increase in price of } \\
\text { land out of the area, etc. }\end{array}$ & 6 & 0.773 \\
\hline \multirow{4}{*}{ 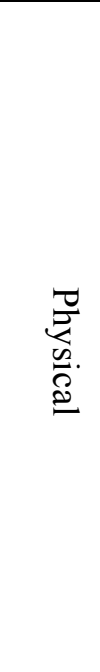 } & $\begin{array}{l}\text { Development } \\
\text { of physical } \\
\text { context }\end{array}$ & $\begin{array}{l}\text { Effect of Padideh on increase in construction in city, } \\
\text { development situation before and after Padideh, } \\
\text { satisfaction with use change caused by Padideh, etc. }\end{array}$ & 10 & 0.838 \\
\hline & $\begin{array}{l}\text { Infrastructura } \\
1 \text { services }\end{array}$ & $\begin{array}{l}\text { Satisfaction with urban services development before } \\
\text { and after Padideh, effect of Padideh on quantitative } \\
\text { and qualitative increase in urban services, etc. }\end{array}$ & 5 & 0.765 \\
\hline & $\begin{array}{l}\text { Pattern of } \\
\text { housing }\end{array}$ & $\begin{array}{l}\text { Change in pattern of construction before and after } \\
\text { Padideh, satisfaction with construction license before } \\
\text { and after Padideh, etc. }\end{array}$ & 5 & 0.702 \\
\hline & $\begin{array}{l}\text { Transportatio } \\
\mathrm{n}\end{array}$ & $\begin{array}{l}\text { Satisfaction with urban and suburban transportation } \\
\text { before and after Padideh, believe in creation a special } \\
\text { transportation network for Padideh, etc. }\end{array}$ & 6 & 0.711 \\
\hline \multirow{3}{*}{ 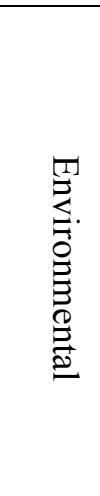 } & $\begin{array}{l}\text { Environment } \\
\text { al landscape }\end{array}$ & $\begin{array}{l}\text { Coordination with Padideh and environmental } \\
\text { conditions of Shandiz, satisfaction with natural } \\
\text { landscape before and after Padideh, etc. }\end{array}$ & 6 & 0.812 \\
\hline & $\begin{array}{c}\text { Health of } \\
\text { environment }\end{array}$ & $\begin{array}{l}\text { Effect of Padideh on pollution of water sources, soil } \\
\text { and weather of city, situation of pollution of water, } \\
\text { soil and weather of city before and after Padideh }\end{array}$ & 8 & 0.642 \\
\hline & $\begin{array}{l}\text { Environment } \\
\text { al hazards }\end{array}$ & $\begin{array}{l}\text { Paying attention to forbidden options of construction } \\
\text { before and after Padideh, effect of Padideh on } \\
\text { reduction of environmental hazards, etc. }\end{array}$ & 7 & 0.599 \\
\hline Total & & - & 113 & 0.873 \\
\hline
\end{tabular}

Reliability of questionnaire was obtained to 0.873 in accordance with Cronbachs' alpha indicating high assurance level. Data analysis of questionnaires has been conducted through descriptive statistics (mean, standard deviation) and inferential statistics (one-sample $t$ test, paired t, gray ranking analysis (GRA) and structural equations (EQS)).

\section{FINDINGS}


Analysis of collected data from statistical samples is considered as an important step of study in scientific studies especially those studies that are experimental and based on collected survey data using interview, observation and questionnaire, because the final results is obtained from this step. In this step of study, the analyzed meaningless data are transformed to understandable information and it would be possible to discuss them and their possible relationships.

\section{PERSONAL CHARACTERISTICS OF RESPONDENTS}

According to descriptive findings, 74.6 percent out of 236 respondents have been men and 25.4 percent of them have been women, 79.2 percent have been married and 69.5 percent of them have had the 3 and 4 member's families in terms of family size. According to assessment of age of respondents, majority of them (38.6\%) have been 31-40 years old and average of age of 35.1 would prove this claim. In terms of education level, 6.5 percent of respondents have elementary degree, 16.1 percent secondary school, 47.8 percent high school, and 28.4 percent of respondents have BA degree or above; job position of respondents indicates that 58.9 percent have been self-employed. According to the evaluation of monthly expenditures of urban households in Shandiz, 40.7 percent of respondents have expenditures between 501 thousands Toman to 1 million Toman (Table 3).

Table 3. Descriptive characteristics of respondents

(Source: Research findings, 2015)

\begin{tabular}{|c|c|c|c|}
\hline \multicolumn{2}{|c|}{ Characteristics } & No & Percent \\
\hline \multirow{2}{*}{ Gender } & Male & 176 & 74.6 \\
\hline & Female & 60 & 25.4 \\
\hline \multirow{5}{*}{ Education } & illiterate & 3 & 1.3 \\
\hline & Primary & 15 & 6.4 \\
\hline & Guidance & 38 & 16.1 \\
\hline & Diploma & 113 & 47.8 \\
\hline & $\begin{array}{l}\text { Bachelor's Degree } \\
\text { or higher }\end{array}$ & 67 & 28.4 \\
\hline \multirow{6}{*}{$\begin{array}{l}\text { Monthly } \\
\text { household } \\
\text { expenses }\end{array}$} & $\begin{array}{l}\text { Less than } 500 \text { Th. } \\
\text { T. }\end{array}$ & 16 & 6.8 \\
\hline & $\begin{array}{l}501 \text { Th. T. to } 1 \mathrm{M} \text {. } \\
\text { T. }\end{array}$ & 96 & 40.7 \\
\hline & 1 to $1.5 \mathrm{M}$. T. & 69 & 29.2 \\
\hline & $\begin{array}{l}1.51 \mathrm{M} \text {. T. to } 2 \mathrm{M} \text {. } \\
\mathrm{T} \text {. }\end{array}$ & 30 & 12.7 \\
\hline & $\begin{array}{l}2.01 \mathrm{M} \text {. T. to } 3 \mathrm{M} \text {. } \\
\text { T. }\end{array}$ & 21 & 8.9 \\
\hline & More than $3 \mathrm{M}$. T. & 4 & 1.7 \\
\hline
\end{tabular}


EFFECT OF PRESENCE OF TOURISM COMPLEX OF PADIDEH ON INDICES OF SUSTAINABLE URBAN DEVELOPMENT

One-sample $t$ test (with theoretical med of 3 ) and paired thave been used to assess the change trend of indices of sustainable urban development, but distribution of data should be normal in order to use mentioned parametric tests. For this purpose, Kolmogorov-Smirnov test has been applied to determine normality of data distribution and the obtained results indicated that distribution of relevant data to indices of sustainable urban development including social security, social motivations, social justice, social identity, job creation, income generation, development of physical context, development of transportation infrastructures, change in environmental landscape, etc.; therefore, parametric tests can be applied in this study.

Table 4. Results of Kolmogorov-Smirnov test of indices of sustainable urban development in Shandiz

(Source: Research findings, 2015)

\begin{tabular}{|c|c|c|c|c|c|c|}
\hline Indic & No. & Mean & $\begin{array}{l}\text { Standard } \\
\text { deviation }\end{array}$ & $\mathbf{Z}$ & Sig. & Result \\
\hline Social security & 236 & 3.25 & 0.943 & 0.918 & 0.368 & Normal \\
\hline Social motivations & 236 & 4.03 & 0.823 & 1.823 & 0.103 & Normal \\
\hline Social justice & 236 & 3.41 & 0.783 & 1.378 & 0.145 & Normal \\
\hline Social identity & 236 & 3.6 & 0.766 & 1.442 & 0.231 & Normal \\
\hline Demographic transformations & 236 & 3.51 & 0.748 & 1.353 & 0.251 & Normal \\
\hline Social participation & 236 & 2.98 & 0.726 & 1.765 & 0.104 & Normal \\
\hline Social awareness & 236 & 3.3 & 0.684 & 1.151 & 0.147 & Normal \\
\hline Life style & 236 & 3.41 & 0.708 & 1.420 & 0.136 & Normal \\
\hline Job creation & 236 & 3.65 & 0.729 & 1.643 & 0.091 & Normal \\
\hline Income generation & 236 & 3.67 & 0.803 & 1.791 & 0.103 & Normal \\
\hline investment & 236 & 3.61 & 0.724 & 1.273 & 0.078 & Normal \\
\hline Land and housing prices & 236 & 3.68 & 0.728 & 1.504 & 0.122 & Normal \\
\hline Development of physical context & 236 & 3.65 & 0.704 & 1.145 & 0.146 & Normal \\
\hline Infrastructural services & 236 & 3.18 & 0.806 & 1.913 & 0.100 & Normal \\
\hline Pattern of housing & 236 & 3.33 & 0.792 & 1.587 & 0.113 & Normal \\
\hline Transportation & 236 & 3.39 & 0.753 & 1.302 & 0.067 & Normal \\
\hline Environmental landscape & 236 & 3.64 & 0.808 & 1.167 & 0.013 & Normal \\
\hline Health of environment & 236 & 2.96 & 0.575 & 1.046 & 0.224 & Normal \\
\hline Environmental hazards & 236 & 3.05 & 0.581 & 1.267 & 0.041 & Normal \\
\hline
\end{tabular}

One-sample t test has been applied to assess the effect of presence of megaproject of tourism complex of Padideh on sustainable urban development in Shandiz; accordingly, the effect level was assessed based on theoretical med of 3 and it was determined that all 19 elements except indices of 
The Turkish Online Journal of Design, Art and Communication - TOJDAC July 2016 Special Edition

social participation and environmental health have had a considerable positive changes toward theoretical med. According to evaluation of $t$ value, it was determined that social motivations with coefficient of $19 / 1$ had the most difference with theoretical med and indices of environmental hazards with coefficient of $1 / 38$ had the lowest difference with standard middle (med).

The results obtained from objective studies about demographic transformations indicate that contrary to past periods (1976-2006) with annual growth rate of urban population $(0 / 1$ to $2 / 5)$ percent yearly, the annual growth rate of population has reached to 6 percent after the establishment of tourism complex of Padideh in Shandiz (2009-2015) (Health Center of Binalood, 2015). Therefore, being optimistic about future, increase in tendency toward living in city and attracting population from other places of country have been occurred after presence of urban megaproject of Padideh. In general, it can be stated that from perspective of citizen's presence of tourism complex of Padideh has changed indices of sustainable urban development in Shandiz.

Table 5. Effect of presence of tourism complex of Padideh on indices of sustainable urban development in Shandiz

(Source: Research findings, 2015)

\begin{tabular}{|c|c|c|c|c|c|}
\hline \multirow{2}{*}{ Row } & \multirow{2}{*}{ Indic } & \multicolumn{4}{|c|}{ Test Value $=3$} \\
\hline & & $\mathbf{t}$ & Mean & Sig & Decision \\
\hline 1 & Social security & 4.088 & 3.2511 & 0.000 & Accept \\
\hline 2 & Social motivations & 19.106 & 4.0237 & 0.000 & Accept \\
\hline 3 & Social justice & 8.144 & 3.4153 & 0.000 & Accept \\
\hline 4 & Social identity & 11.998 & 3.5985 & 0.000 & Accept \\
\hline 5 & Demographic transformations & 10.419 & 3.5074 & 0.000 & Accept \\
\hline 6 & Social participation & -0.508 & 2.9760 & 0.612 & No accept \\
\hline 7 & Social awareness & 6.759 & 3.3008 & 0.000 & Accept \\
\hline 8 & Life style & 8.854 & 3.4078 & 0.000 & Accept \\
\hline 9 & Job creation & 13.767 & 3.6531 & 0.000 & Accept \\
\hline 10 & Income generation & 12.830 & 3.6709 & 0.000 & Accept \\
\hline 11 & investment & 12.915 & 3.6085 & 0.000 & Accept \\
\hline 12 & Land and housing prices & 14.445 & 3.6847 & 0.000 & Accept \\
\hline 13 & Development of physical context & 14.185 & 3.6497 & 0.000 & Accept \\
\hline 14 & Infrastructural services & 3.533 & 3.1854 & 0.000 & Accept \\
\hline 15 & Pattern of housing & 6.352 & 3.3273 & 0.000 & Accept \\
\hline 16 & Transportation & 8.040 & 3.3941 & 0.000 & Accept \\
\hline 17 & Environmental landscape & 12.232 & 3.6432 & 0.000 & Accept \\
\hline 18 & Health of environment & -1.051 & 2.9607 & 0.294 & No accept \\
\hline
\end{tabular}


The Turkish Online Journal of Design, Art and Communication - TOJDAC July 2016 Special Edition

\begin{tabular}{|c|c|c|c|c|c|}
\hline 19 & Environmental hazards & 1.382 & 3.0523 & 0.016 & Accept \\
\hline
\end{tabular}

A criterion has been use in this study to determine the rank of gray relationship between indices of sustainable urban development; accordingly, the more the value is closer to desired value, the better the situation is. Therefore, indices with significance level more than $0 / 05$ and negative $t$ value have not been entered to the analysis of gray relationship before passing different steps of analysis of gray relationship rank using one-sample $t$ analysis; hence, 17 indices of sustainable urban development out of 19 considered indices were entered to analysis of gray relationship analysis.

Table 6. Ranking of impressibility of indices of sustainable urban development in Shandiz based on gray rank

(Source: Research findings, 2015)

\begin{tabular}{|c|c|c|c|}
\hline Row & Indic & Score & $\overline{R a n k}$ \\
\hline 1 & Social security & 0.222 & 15 \\
\hline 2 & Social motivations & 0.664 & 1 \\
\hline 3 & Social justice & 0.259 & 10 \\
\hline 4 & Social identity & 0.317 & 8 \\
\hline 5 & Demographic transformations & 0.285 & 9 \\
\hline 6 & Social awareness & 0.232 & 14 \\
\hline 7 & Life style & 0.257 & 11 \\
\hline 8 & Job creation & 0.340 & 4 \\
\hline 9 & Income generation & 0.348 & 3 \\
\hline 10 & investment & 0.321 & 7 \\
\hline 11 & Land and housing prices & 0.355 & 2 \\
\hline 12 & Development of physical context & 0.338 & 5 \\
\hline 13 & Infrastructural services & 0.210 & 16 \\
\hline 14 & Pattern of housing & 0.238 & 13 \\
\hline 15 & Transportation & 0.253 & 12 \\
\hline 16 & Environmental landscape & 0.335 & 6 \\
\hline 17 & Environmental hazards & 0.190 & 17 \\
\hline
\end{tabular}

According to the obtained results from conducted steps of gray relationship analysis, among 17 entered indices to model social motivations, changes in land and housing prices and income generation have been at ranks of first to third with coefficients of $0.348,0.355$ and 0.664 in terms of being affected by presence of Padideh project. 


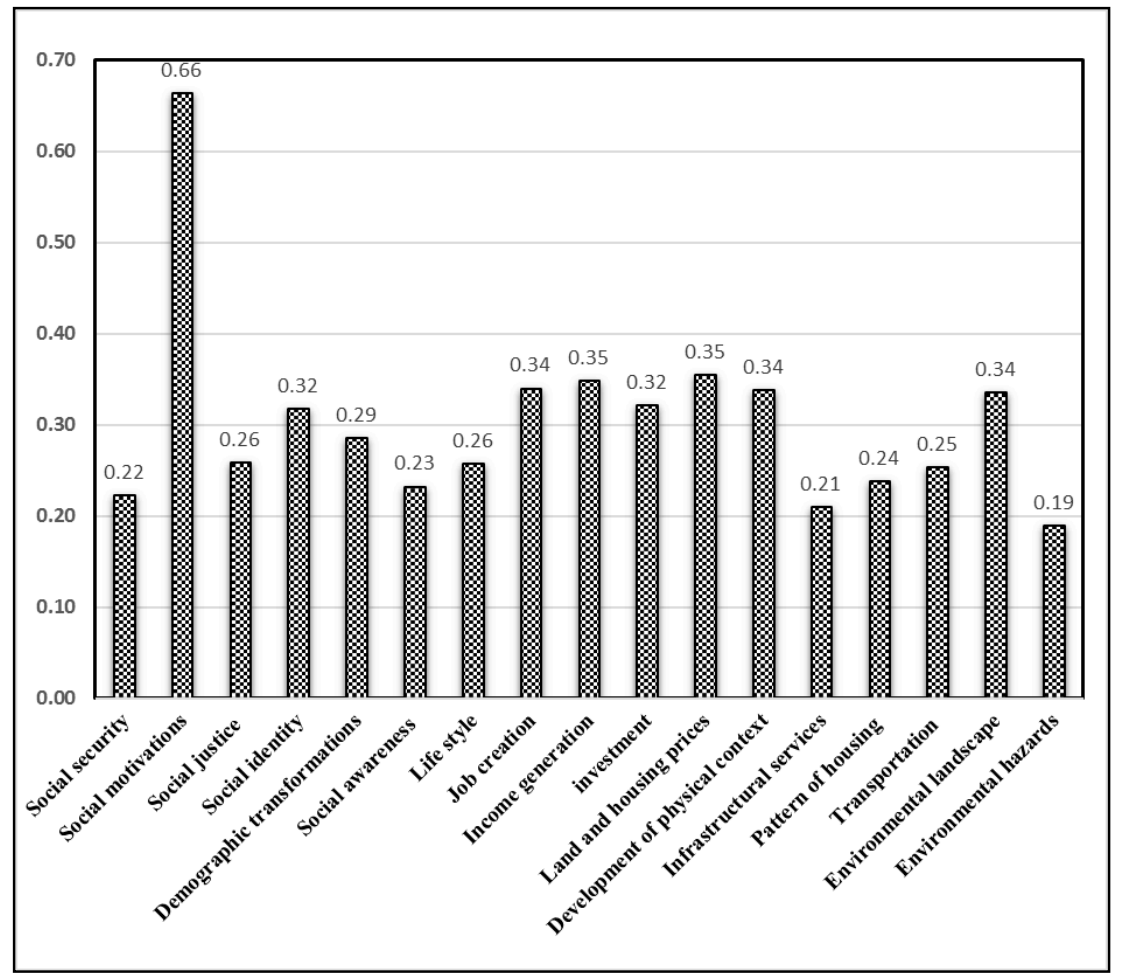

Figure 3. Ranking of indices of sustainable urban development

(Source: Research findings, 2015)

Using the results obtained from one-sample $t$ test and analysis of gray relationship rank, it would be stated despite the stopped project due to financial problems of shareholder's presence of megaproject of Padideh has increased optimism toward future among citizens, has changed prices of lands and housing and has increased income of citizens during short time (2009-2015).

\section{ASSESSMENT OF CHANGES IN INDICES OF SUSTAINABLE URBAN DEVELOPMENT BECAUSE OF THE PRESENCE OF TOURISM COMPLEX OF PADIDEH IN SHANDIZ}

The questions of questionnaire have evaluated the situation of 19 indices of sustainable urban development before and after presence of tourism complex of Padideh from the perspective of citizens in order to be aware of changing trend of these indices. These questions have been used through paired tow-sample $t$ test to evaluate the changes in indices compared to their situation before presence of Padideh. 
The Turkish Online Journal of Design, Art and Communication - TOJDAC July 2016 Special Edition

Table 7. Comparison between indices of sustainable urban development before and after Padideh

(Source: Research findings, 2015)

\begin{tabular}{|c|c|c|c|c|c|}
\hline \multicolumn{2}{|l|}{ Indic } & \multirow{2}{*}{$\frac{\text { Mean }}{} \frac{}{3.24}$} & \multirow{2}{*}{$\begin{array}{l}\text { No. } \\
236\end{array}$} & \multirow{2}{*}{\begin{tabular}{|c|} 
Std. Deviation \\
1.017 \\
\end{tabular}} & \multirow{2}{*}{$\begin{array}{c}\begin{array}{c}\text { Std. Error } \\
\text { Mean }\end{array} \\
0.066 \\
\end{array}$} \\
\hline Social security & Fr. & & & & \\
\hline & Af. & 3.02 & 236 & 1.159 & 0.075 \\
\hline \multirow{2}{*}{ Social motivations } & Fr. & 3.44 & 236 & 1.340 & 0.087 \\
\hline & Af. & 4.05 & 236 & 1.077 & 0.070 \\
\hline \multirow{2}{*}{ Social justice } & Fr. & 3.19 & 236 & 1.016 & 0.066 \\
\hline & Af. & 3.95 & 236 & 1.024 & 0.067 \\
\hline \multirow[t]{2}{*}{ Social identity } & Fr. & 3.27 & 236 & 1.286 & 0.084 \\
\hline & Af. & 4.03 & 236 & 1.014 & 0.066 \\
\hline \multirow{2}{*}{$\begin{array}{l}\text { Demographic } \\
\text { transformations }\end{array}$} & Fr. & 2.53 & 236 & 1.085 & 0.071 \\
\hline & Af. & 4.10 & 236 & .935 & 0.061 \\
\hline \multirow[t]{2}{*}{ Social awareness } & Fr. & 2.80 & 236 & .968 & 0.063 \\
\hline & Af. & 3.13 & 236 & 1.126 & 0.073 \\
\hline \multirow[t]{2}{*}{ Social participation } & Fr. & 2.89 & 236 & 1.040 & 0.068 \\
\hline & Af. & 3.66 & 236 & 1.128 & 0.073 \\
\hline \multirow[t]{2}{*}{ Life style } & Fr. & 3.15 & 236 & 1.051 & 0.068 \\
\hline & Af. & 3.47 & 236 & 1.085 & 0.071 \\
\hline \multirow{2}{*}{ Job creation } & Fr. & 2.69 & 236 & 1.096 & 0.071 \\
\hline & Af. & 3.99 & 236 & 1.044 & 0.068 \\
\hline \multirow[t]{2}{*}{ Income generation } & Fr. & 2.98 & 236 & .961 & 0.063 \\
\hline & Af. & 3.60 & 236 & 1.065 & 0.069 \\
\hline \multirow[t]{2}{*}{ investment } & Fr. & 2.66 & 236 & 1.082 & 0.070 \\
\hline & Af. & 3.91 & 236 & 1.025 & 0.067 \\
\hline \multirow{2}{*}{$\begin{array}{c}\text { Land and housing } \\
\text { prices }\end{array}$} & Fr. & 3.00 & 236 & .961 & 0.063 \\
\hline & Af. & 4.04 & 236 & .938 & 0.061 \\
\hline \multirow{2}{*}{$\begin{array}{l}\text { Development of } \\
\text { physical context }\end{array}$} & Fr. & 2.72 & 236 & .950 & 0.062 \\
\hline & Af. & 3.65 & 236 & 1.039 & 0.068 \\
\hline \multirow{2}{*}{$\begin{array}{l}\text { Infrastructural } \\
\text { services }\end{array}$} & Fr. & 2.71 & 236 & .900 & 0.059 \\
\hline & Af. & 3.34 & 236 & 1.058 & 0.069 \\
\hline \multirow[t]{2}{*}{ Pattern of housing } & Fr. & 2.71 & 236 & .977 & 0.064 \\
\hline & Af. & 3.58 & 236 & 1.014 & 0.066 \\
\hline \multirow[t]{2}{*}{ Transportation } & Fr. & 2.52 & 236 & 1.021 & 0.066 \\
\hline & Af. & 3.51 & 236 & 1.105 & 0.072 \\
\hline \multirow{2}{*}{$\begin{array}{l}\text { Environmental } \\
\text { landscape }\end{array}$} & Fr. & 3.34 & 236 & 1.109 & 0.072 \\
\hline & Af. & 3.90 & 236 & 1.012 & 0.066 \\
\hline \multirow{2}{*}{$\begin{array}{l}\text { Health of } \\
\text { environment }\end{array}$} & Fr. & 2.56 & 236 & 1.107 & 0.072 \\
\hline & Af. & 2.89 & 236 & 1.157 & 0.075 \\
\hline \multirow{2}{*}{$\begin{array}{l}\text { Environmental } \\
\text { hazards }\end{array}$} & Fr. & 2.72 & 236 & 1.099 & 0.072 \\
\hline & Af. & 2.87 & 236 & 1.150 & 0.075 \\
\hline
\end{tabular}

According to table 7, 19 indices of sustainable urban development except social security and justice have been positively affected by presence of tourism complex of Padideh. Although the value of 
The Turkish Online Journal of Design, Art and Communication - TOJDAC July 2016 Special Edition social security is positive, but it indicates increase in social gap between citizens living in city of Shandiz.

Table 8. Level of changes in indices of sustainable urban development caused by Padideh (Source: Research findings, 2015)

\begin{tabular}{|c|c|c|c|c|c|c|c|c|}
\hline \multirow{3}{*}{ Indic } & \multicolumn{5}{|c|}{ Paired Differences } & \multirow{3}{*}{$\mathbf{t}$} & \multirow{3}{*}{ df } & \multirow{3}{*}{ Sig } \\
\hline & \multirow[t]{2}{*}{ Mean } & \multirow{2}{*}{$\begin{array}{c}\text { Std. } \\
\text { Deviation }\end{array}$} & \multirow{2}{*}{$\begin{array}{l}\text { Std. } \\
\text { Error } \\
\text { Mean }\end{array}$} & \multicolumn{2}{|c|}{$\begin{array}{l}\text { 95\% Confidence } \\
\text { Interval of the } \\
\text { Difference }\end{array}$} & & & \\
\hline & & & & Lower & Upper & & & \\
\hline Social security & .225 & 1.705 & .111 & .006 & .443 & 2.024 & 235 & .044 \\
\hline Social motivations & -.606 & 1.627 & .106 & -.815 & -.397 & -5.720 & 235 & .000 \\
\hline Social justice & -.763 & 1.296 & .084 & -.929 & -.597 & -9.041 & 235 & .000 \\
\hline Social identity & -.754 & 1.420 & .092 & -.936 & -.572 & -8.161 & 235 & .000 \\
\hline $\begin{array}{l}\text { Demographic } \\
\text { transformations }\end{array}$ & -1.568 & 1.381 & .090 & -1.745 & -1.391 & -17.445 & 235 & .000 \\
\hline Social participation & -.331 & 1.496 & .097 & -.522 & -.139 & -3.393 & 235 & .001 \\
\hline Social awareness & -.763 & 1.558 & .101 & -.963 & -.563 & -7.519 & 235 & .000 \\
\hline Life style & -.318 & 1.361 & .089 & -.492 & -.143 & -3.588 & 235 & .000 \\
\hline Job creation & -1.297 & 1.575 & .103 & -1.499 & -1.095 & -12.644 & 235 & .000 \\
\hline Income generation & -.619 & 1.529 & .100 & -.815 & -.423 & -6.214 & 235 & .000 \\
\hline investment & -1.254 & 1.649 & .107 & -1.466 & -1.043 & -11.687 & 235 & .000 \\
\hline Land and housing prices & -1.042 & 1.307 & .085 & -1.210 & -.875 & -12.250 & 235 & .000 \\
\hline $\begin{array}{l}\text { Development of physical } \\
\text { context }\end{array}$ & -.936 & 1.408 & .092 & -1.117 & -.756 & -10.215 & 235 & .000 \\
\hline Infrastructural services & -.627 & 1.290 & .084 & -.793 & -.462 & -7.467 & 235 & .000 \\
\hline Pattern of housing & -.869 & 1.354 & .088 & -1.042 & -.695 & -9.854 & 235 & .000 \\
\hline Transportation & -.992 & 1.371 & .089 & -1.167 & -.816 & -11.107 & 235 & .000 \\
\hline Environmental landscape & -.564 & 1.576 & .103 & -.766 & -.361 & -5.492 & 235 & .000 \\
\hline Health of environment & -.335 & 1.344 & .087 & -.507 & -.162 & -3.826 & 235 & .000 \\
\hline
\end{tabular}


The Turkish Online Journal of Design, Art and Communication - TOJDAC July 2016 Special Edition

\begin{tabular}{|c|c|c|c|c|c|c|c|c|}
\hline Environmental hazards & -.153 & 1.259 & .082 & -.314 & .009 & -1.861 & 235 & .064 \\
\hline
\end{tabular}

Paired two-sample $t$ test has been applied to determine the difference between indices of sustainable urban development before and after presence of Padideh. According to the obtained results, among indices (except social security), demographic transformations with value of -17.44 had the most changes and then index of income generation with coefficient of -12.64 was at second rank. Therefore, presence of tourism complex of Padideh has attracted population, immigrants, and increased job opportunities in Shandiz. The lowest change in indices was related to respecting environmental hazard by citizens of Shandiz.

\section{ANALYSIS OF EFFECT OF TOURISM COMPLEX OF PADIDEH ON ASPECTS OF SUSTAINABLE URBAN DEVELOPMENT IN SHANDIZ}

One-sample $t$ test (with theoretical med of 3 ) and paired $t$ have been used to assess the change trend of indices of sustainable urban development, but distribution of data should be normal in order to use mentioned parametric tests. For this purpose, Kolmogorov-Smirnov test has been applied to determine normality of data distribution and the obtained results indicated that distribution of relevant data to indices of sustainable urban development including social, economic, physical and environmental indices. Therefore, parametric tests can be applied in this study. According to t value of test, economic index of sustainable urban development with coefficient of 24.15 has been more affected by presence of tourism complex Padideh and the lowest effect has been related to environmental aspect of sustainable urban development with coefficient of 6.39. In general, it can be stated that from perspective of citizen's presence of tourism complex of Padideh has considerably changed indices of sustainable urban development in Shandiz. According to $t$ value of 14.37 (at Sig $<0.01$ ), there is a significant difference between citizens' view and theoretical med of this test.

Table 9. Effect of presence of tourism complex of Padideh on indices of sustainable urban development in Shandiz

(Source: Research findings, 2015)

\begin{tabular}{|c|c|c|c|c|c|c|}
\hline \multirow{3}{*}{ Dimension } & \multicolumn{6}{|c|}{ Test Value $=3$} \\
\hline & \multirow{2}{*}{$\mathbf{t}$} & \multirow{2}{*}{ df } & \multirow{2}{*}{$\begin{array}{l}\text { Sig. (2- } \\
\text { tailed) }\end{array}$} & \multirow{2}{*}{$\begin{array}{c}\text { Mean } \\
\text { Differen } \\
\text { ce }\end{array}$} & \multicolumn{2}{|c|}{$\begin{array}{c}95 \% \text { Confidence Interval } \\
\text { of the Difference }\end{array}$} \\
\hline & & & & & Lower & Upper \\
\hline Social & 9.640 & 235 & .000 & .38649 & .3075 & .4655 \\
\hline Economical & 24.152 & 235 & .000 & 1.03702 & .9524 & 1.1216 \\
\hline Physical & 10.880 & 235 & .000 & .44857 & .3673 & .5298 \\
\hline Environmental & 6.394 & 235 & .000 & .18079 & .1251 & .2365 \\
\hline SUD & 14.377 & 235 & .000 & .49184 & .4244 & .5592 \\
\hline
\end{tabular}

The questions of questionnaire have evaluated the situation of aspects of sustainable urban development before and after presence of tourism complex of Padideh from the perspective of citizens in order to be aware of changing trend of these aspects. These questions have been used through paired tow-sample $t$ test to evaluate the changes in aspects compared to their situation before presence of Padideh. According to table 10, 4 aspects of sustainable urban development have been positively

Submit Date: 10.05.2016, Acceptance Date: 25.06.2016, DOI NO: 10.7456/1060JSE/005 
The Turkish Online Journal of Design, Art and Communication - TOJDAC July 2016 Special Edition

affected by presence of tourism complex of Padideh. According to the perspective of citizens, there has been a considerable change and difference in physical aspect of sustainable urban development before and after presence of Padideh.

Table 10. Comparison between aspects of sustainable urban development before and after Padideh

(Source: Research findings, 2015)

\begin{tabular}{|c|c|c|c|c|c|}
\hline \multicolumn{2}{|c|}{ Dimension } & Mean & No. & Std. Deviation & $\begin{array}{c}\text { Std. Error } \\
\text { Mean }\end{array}$ \\
\hline \multirow{2}{*}{ Social } & Fr. & 3.0646 & 236 & .65644 & .04273 \\
\cline { 2 - 6 } & Af. & 3.6743 & 236 & .64342 & .04188 \\
\hline \multirow{2}{*}{ Economical } & Fr. & 3.1557 & 236 & .56762 & .03695 \\
\cline { 2 - 6 } & Af. & 3.8104 & 236 & .72991 & .04751 \\
\hline \multirow{2}{*}{ Physical } & Fr. & 2.6642 & 236 & .71481 & .04653 \\
\cline { 2 - 6 } & Af. & 3.5201 & 236 & .74653 & .04859 \\
\hline \multirow{2}{*}{ Environmental } & Fr. & 2.8715 & 236 & .73800 & .04804 \\
\cline { 2 - 6 } & Af. & 3.2218 & 236 & .59093 & .03847 \\
\hline \multirow{2}{*}{$\begin{array}{l}\text { Sustainable urban } \\
\text { development(SUD }\end{array}$} & Fr. & 2.9008 & 236 & .54830 & .03569 \\
\cline { 2 - 6 } & Af. & 3.5598 & 236 & .54040 & .03518 \\
\hline
\end{tabular}

Paired two-sample $t$ test has been applied to determine the difference between aspects of sustainable urban development before and after presence of Padideh. According to the obtained results, among aspects, physical aspect of sustainable urban development with value of -13.24 had the most changes and then environmental aspect with value of -6.808 had the lowest changes. The results obtained from objective studies on maps of land use of Shandiz indicate that trend of physical changes (development of physical context of city) has been equal to 2.35 percent during 1998-2009 but this amount has been annually increased to 5 percent after establishment of tourism complex of Padideh during 2009-2015 indicating a considerable effect of the megaproject on physical changes in Shandiz (Ahmadi, 1998 \& consultant engineers of Farnahad, 2010). Therefore, presence of tourism complex of Padideh has considerably changed sustainable urban development in Shandiz and this issue is proved by $t$ value of -13.54 (at $\operatorname{Sig}<0.001$ ).

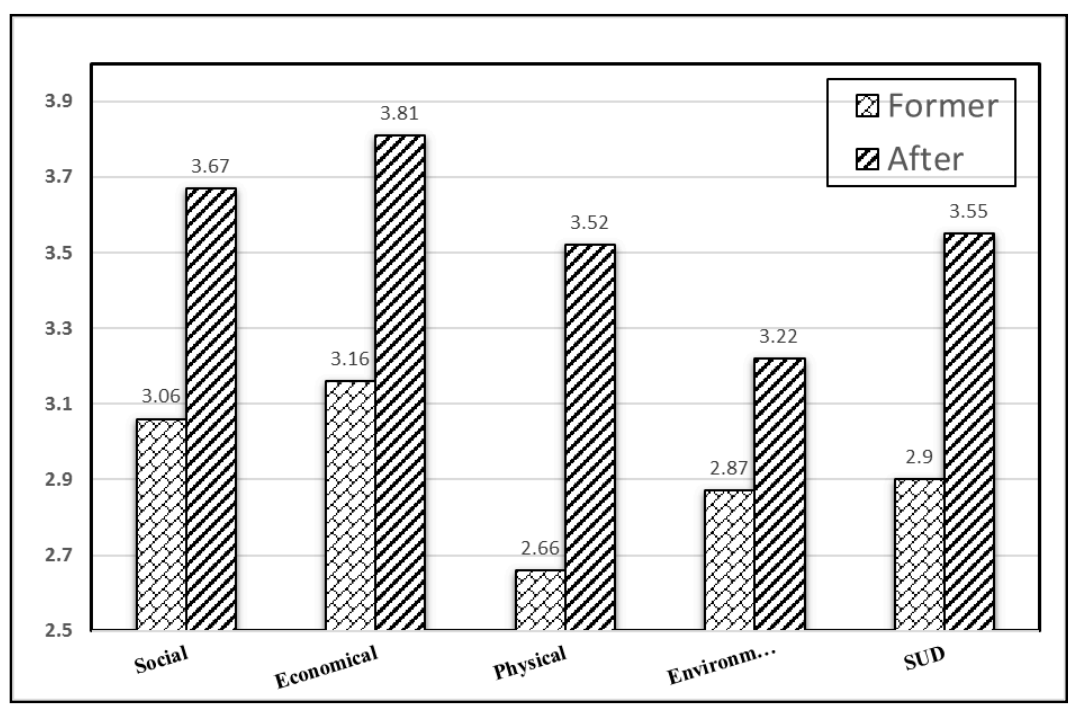


The Turkish Online Journal of Design, Art and Communication - TOJDAC July 2016 Special Edition

Figure 4. Comparison between Dimension of sustainable urban development before and after Padideh

(Source: Research findings, 2015)

Table 11. Assessment of changes in aspects of sustainable urban development because using paired t-test

(Source: Research findings, 2015)

\begin{tabular}{|c|c|c|c|c|c|c|c|c|}
\hline \multirow{3}{*}{ Dimension } & \multicolumn{5}{|c|}{ Paired Differences } & \multirow{3}{*}{$\mathbf{t}$} & \multirow{3}{*}{ df } & \multirow{3}{*}{ Sig } \\
\hline & \multirow[t]{2}{*}{ Mean } & \multirow{2}{*}{$\begin{array}{c}\text { Std. } \\
\text { Deviation }\end{array}$} & \multirow{2}{*}{$\begin{array}{l}\text { Std. } \\
\text { Error } \\
\text { Mean }\end{array}$} & \multicolumn{2}{|c|}{$\begin{array}{l}95 \% \text { Confidence } \\
\text { Interval of the } \\
\text { Difference }\end{array}$} & & & \\
\hline & & & & Lower & Upper & & & \\
\hline Social & -.60964 & .91222 & .05938 & -.72663 & -.49265 & -10.267 & 235 & .000 \\
\hline Economical & -.65466 & .80914 & .05267 & -.75843 & -.55089 & -12.429 & 235 & .000 \\
\hline Physical & -.85593 & .99301 & .06464 & -.98328 & \begin{tabular}{|l|}
-.72859 \\
\end{tabular} & -13.242 & 235 & .000 \\
\hline Environmental & -.35028 & .79042 & .05145 & -.45165 & \begin{tabular}{|l|}
-.24892 \\
\end{tabular} & -6.808 & 235 & .000 \\
\hline SUD & -.65901 & .74757 & .04866 & -.75488 & -.56314 & -13.542 & 235 & .000 \\
\hline
\end{tabular}

Path analysis has been applied through EQS software to assess the effect of social, economic, physical and environmental aspects and indices on sustainable development and the obtained results are presented in table 12 and diagram 5. The fitness of specified model should be assessed at first. The obtained results indicate that amount of RMSEA of model is equal to $0 / 001$ that is lower than $0 / 1$; hence, RMESA of model is good and the model is accepted. The value of Chi-square is equal t0 $0 / 817$ that is lower than 3; the value of indices of GFI, CFI and NFI have been more than 0/9 indicating that the measurement model of variables has been a good model. Now the third hypothesis of study should be evaluated using this model.

The obtained results of path analysis indicate that path coefficient of social aspect toward variable of sustainable urban development is equal to 0.61 with approximate p-value of 0.0005 that is lower the error level of 0.01 ; hence it is significant. Path coefficient of economic aspect toward sustainable urban development is equal to $0 / 45$ with approximate p-value of 0.0005 that is lower the error level of 0.01 ; hence it is significant and Path coefficient of physical aspect toward sustainable urban development is equal to 0.46 with approximate p-value of 0.008 that is above the error level of 0.01 , hence it is significant. Accordingly, it can be stated that social, economic, physical and environmental aspects can effect on sustainable urban development at assurance level of $99 \%$ so that with increase in them the rate of balance would be more tending toward positive values; in other words, this increase would increase sustainable urban development.

Table 12. Indices of fitness of path analysis test through EQS

(Source: Research findings, 2015)

\begin{tabular}{|c|c|c|c|}
\hline Exam & Description & $\begin{array}{c}\text { Acceptable } \\
\text { values }\end{array}$ & $\begin{array}{c}\text { Obtained } \\
\text { values }\end{array}$ \\
\hline
\end{tabular}


The Turkish Online Journal of Design, Art and Communication - TOJDAC July 2016 Special Edition

\begin{tabular}{|c|c|c|c|}
\hline $\mathrm{X}^{2} / \mathrm{df}$ & Chi-square relative & $<3$ & 0.82 \\
\hline RMSEA & $\begin{array}{c}\text { The root mean square error } \\
\text { of approximation }\end{array}$ & $<0.1$ & 0.05 \\
\hline GFI & Modified fitness index & $>0.9$ & 0.99 \\
\hline NFI & Soft fit index & $>0.9$ & 0.98 \\
\hline CFI & Comparative fit index & $>0.9$ & 0.999 \\
\hline
\end{tabular}

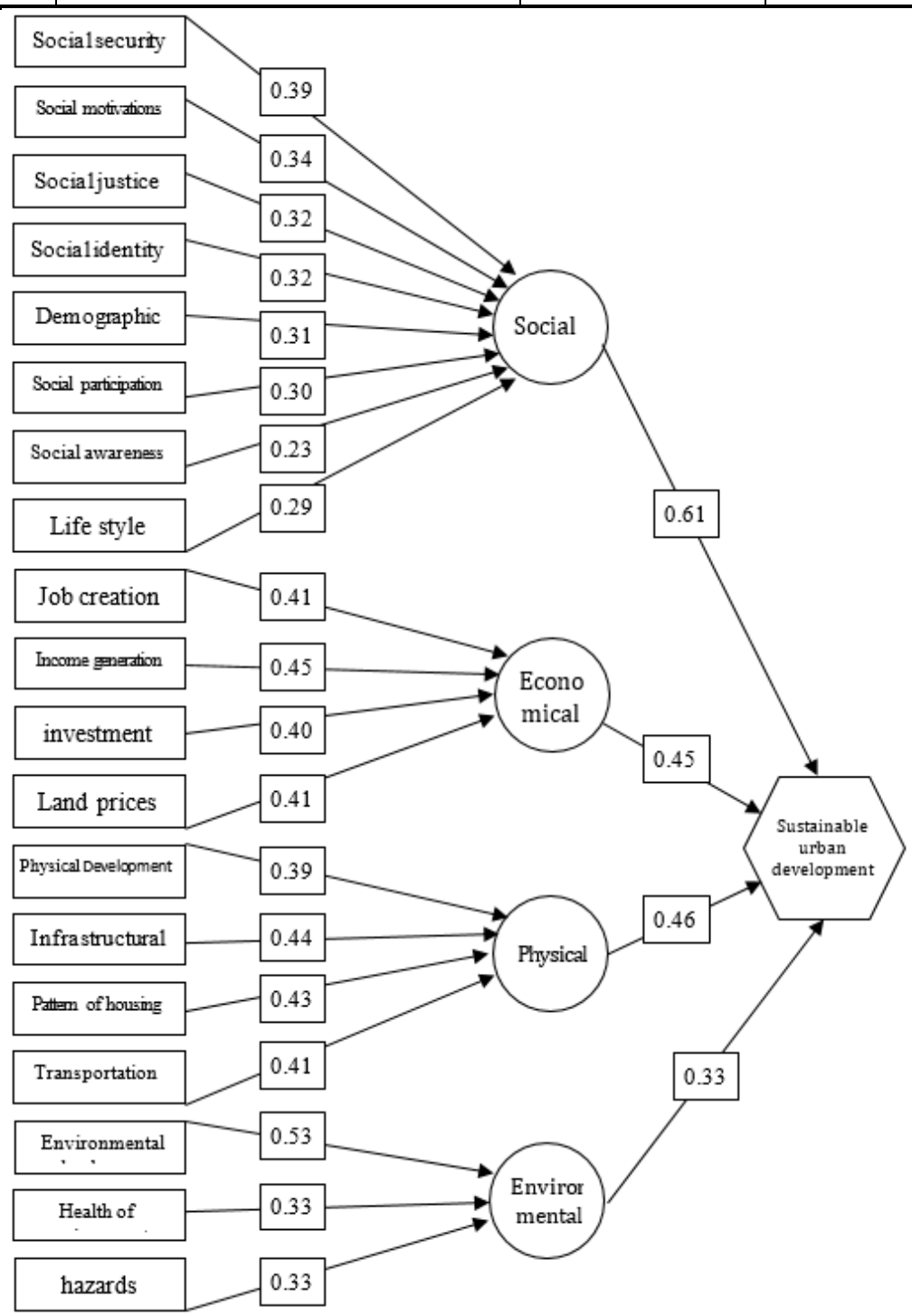

Figure 5. The effect level of indices and aspect on sustainable urban development in Shandiz with presence of Padideh

(Source: Research findings, 2015)

\section{CONCLUSION AND RECOMMENDATIONS}

Megaprojects are projects with large scale that can change landscapes through a rapid process. These projects tend to re-illustrate the city and increase its attractiveness and completion power as well as economic growth and development while they face some oppositions so that it would be a 
question if these projects have long-term benefits or not and if the city acts in favor of all residents in long-term period. Therefore, this study was conducted to assess indices and aspects of sustainable urban development. The obtained results of this study was coordinated with results of studies conducted by Anabestani et al (2013) indicating that presence of megaproject of tourism complex of Padideh has had the most effect on economic aspect of sustainable urban development during short time $(2009,2015)$ from perspective of citizens; based on the results obtained from this study that is coordinated with results of conducted study by Pahlavan (2013), this project has considerably changed physical aspect of sustainable urban development compared to past. Moreover, this megaproject has considerably increased land and housing prices based on the obtained results that are coordinated with results obtained from conducted studies by Anabestani et al (2014).

This study was conducted to response this question: what are the changes in aspects and indices of sustainable urban development after presence of tourism complex and establishment of dream city of Padideh during 2009-2015 from the perspective of citizens? According to the obtained findings and results from survey of citizens of Shandiz, among 19 indices of sustainable urban development the following indices have been mostly affected by presence of tourism complex of Padide in this city: social motivations (being optimistic about future of living in city of Shandiz), increase in prices of land and housing and income generation while some indices such as social participation and health had not been directly affected. In addition, economic aspect of sustainable urban development among other aspect had been mostly affected based on the value of 24.15 obtained from one-sample $t$ test. According to perspective of citizens, physical aspect has been mostly changed after presence of Padideh. Therefore, presence and activities of tourism complex of Padideh in Shandiz have had many effects on indices and aspects of sustainable urban development of Shandiz; hence, the hypothesis of this study has been accepted.

There are some recommendations in accordance with obtained results from this study:

Development of infrastructures of urban and trans-urban transportations (creating a special transportation network from Mashhad to Padideh along with quantitative and qualitative development of urban services) through encouraging investors of megaprojects to participate in these urban issues

$>\quad$ The project of dream city of Padide has not been completed yet; hence, there will be considerable transformations in markets of land and housing of this summer area located in suburb of Mashhad if it is completed. Therefore, urban managers should make required policies to control land and housing markets during this transition period.

In accordance with changes in future markets of land and housing, there will be more nonnative population in this city that was a limited social area in past; therefore, there will be a multiple social context making social conflicts in region and city. Hence, it would be essential to pay more attention to main residents of city in accordance with social justice and sustainable development.

$>\quad$ Supervision of urban management on construction permissions for commercial, residential, and visiting units and paying attention to coordination between uses to prevent from undesired changes in per capita urban lands.

Strengthening relevant infrastructure to creation of new job opportunities with the aim of innovation and use of local and indigenous capacities (such as handicrafts, horticultural crops, native foods, local ceremonies) to gain more income and protect native culture of citizens of Shandiz.

$>\quad$ It would be important to prepare a calm environment with economic and social security in city of Shandiz during a large investment like establishment of Tourism Company of Padideh and it symbol that is Dream City of Padideh. Security and calmness of this region is a symbol of its development that can attract more tourists to visit this region. 


\section{REFERENCES}

Abdulaal, W. A. (2012). Large urban developments as the new driver for land development in Jeddah. Habitat International, 36(1), 36-46.

Ahmadi, N. (1998). Guidance Plan of Shandiz City. Mashhad: Khorasan Governor. [In Persian]

Altshuler, A. \& Luberoff, D. (2003). Mega-projects. the changing politics of urban public investment. Washington, DC: Brookings Institution Press.

Anabestani, A. A. \& Anabestani, Z. (2013). The survey of role of passive defense in the location of urban Mega-projects (Case study: Padideh Tourism Complex). Proceeding of $6^{\text {th }}$ Conference of Iranian Geopolitics’ Association, Mashhad. [In Persian]

Anabestani, A. A., Ziari, Y. \& Anabestani, Z. (2013). The survey of effects of Padideh Tourism Company on urban development in Shandiz. Journal of Tourism Planning \& Development, 2(2), 163-185. [In Persian]

Anabestani, Z., Anabestani, A. A. \& Ziari, Y. (2014). The effect of Mega-project on land and urban housing market (Case study: Shandiz city). Proceeding of $6^{\text {th }}$ Conference of Urban Planning \& Management, Mashhad. [In Persian]

Azizi. M. M. (2001). Sustainable urban development, Interpretation and analysis of worldviews. Journal of Soffeh, 11(33), 14-27. [In Persian]

Blowers, A., (1994). Planning for sustainable environment. A report the town and country planning association, London, Ear Thescam Pub,

Boano, C., Lamarca, M. G., \& Hunter, W. (2011). The frontlines of contested urbanism megaprojects and mega-resistances in Dharavi. Journal of Developing Societies, 27(3-4), 295-326.

Bornstein, L. (2010). Mega-projects, city-building and community benefits. City, Culture and Society, 1(4), 199-206.

Consulting Engineers of Farnahad. (2010). Master plan of civil \& development of shandiz. Mashhad: Rzavi Khorasan Governor. [In Persian]

Divandari, A., Ekhlassi, A., \& Rahmani, K. (2014). Devising a branding model for multipurpose mega-projects in entertainment, residential, tourism, and sport in Iran. Journal of Vacation Marketing, 20(1), 73-91.

Douglass, M. (2005). Globalization, Mega-Projects and the Environment: Urban Form and Water in Jakarta, Globalization Research Center and Department of Urban and Regional Planning University of Hawai'i.

Eskandari-e-Sani, M. (2017). Sustainable urban development planning, case study: Mashhad. Unpublished Master thesis, Yazd University. [In Persian]

Flyvbjerg, B., Bruzelius, N. \& Rothengatter, W. (2003). Megaprojects and Risk: An Anatomy of Ambition, Cambridge: Cambridge University Press.

Follmann, A. (2015). Urban mega-projects for a 'world-class' riverfront-the interplay of informality, flexibility and exceptionality along the Yamuna in Delhi, India. Habitat International, 45(1), 213-222.

Hall, P., (1993). Toward Sustainable, Live able and Innovative Cities for 21 Set Century. In proceeding of the Third Conference of the World Capitals, Tokyo, Pp. 22-28.

Health Center of Binalood County. (2015). Population information of Shandiz city and countryside villages. Mashhad. [In Persian]

Hwang, J. T. (2014). Territorialized urban mega-projects beyond global convergence: The case of Dongdaemun Design Plaza \& Park Project, Seoul. Cities, 40(1), 82-89.

International Development Company tourism industry of Padideh in Shandiz. (2015). Information on the City visionary of Padideh. Retrieved 22 December 2015 from http://www.padide.com. [In Persian]

Jia, G., Yang, F., Wang, G., Hong, B., \& You, R. (2011). A study of mega project from a perspective of social conflict theory. International Journal of project management, 29(7), 817-827.

Kalantari, M. (2006). The planning of sustainable urban development with emphasize on physical development, case study: Tafresh city. Unpublished Master thesis, Tarbiat Modarres University, Tehran. [In Persian]

Kanaroglou, P., 2009, A Tool for Evaluating Urban Sustainability via Integrated Transportation and land Use Simulation Models, Environment Urban/ Urban Environment, 3(1), 28 - 49. 
Mahmoodinezhad, H. (2006). Sustainable urban development, by internal and external variables, exploration in relation to sustainable development. Journal of Civil (Civil Engineering, Architecture and Urbanism), 4(35), 10-15. [In Persian]

Mok, K. Y., Shen, G. Q., \& Yang, J. (2015). Stakeholder management studies in mega construction projects: A review and future directions. International Journal of Project Management, 33(2), 446457.

Orueta, F. D., \& Fainstein, S. S. (2008). The New Mega-Projects: Genesis and Impacts. International Journal of Urban and Regional Research, 32(4), 759-767.

Pahlavan, S. (2013). The effects of the creation of urban Mega-project on community development process (Case study: Mashhad Almas shargh). Unpublished Master thesis, Tarbiat Modarres University, Tehran. [In Persian]

Ponzini, D. (2011). Large Scale Development Projects and Star Architecture in the Absence of Democratic Politics: The Case of Abu Dhabi, UAE, Cities, 28(3), 251-259.

Poujafar, M. R., Khodaie, Z. \& Poukhieri, A. (2011). Analysis on understanding components, indicators and classic sustainable urban development. Journal of Iranian Social Development Studies, 3(3), 25-36. [In Persian]

Priemus, H., \& van Wee, B. (Eds.). (2013). International Handbook on Mega-projects. Edward Elgar Publishing.

Priemus, H., Flyvbjerg, B., \& van Wee, B. (Eds.). (2008). Decision-making on mega-projects: costbenefit analysis, planning and innovation. Edward Elgar Publishing.

Qarakhlou, M. \& Hosieni, S. H. (2006). Indic of sustainable urban development. Journal of Geography \& Regional Development, 4(8), 157-177. [In Persian]

Rzavi Khorasan Governor. (2015). Last country division of Binalood County. Mashhad: Rzavi Khorasan Governor. [In Persian]

Statistic Center of Iran. (2011). General population and housing census- Binalood County. Tehran: SCI Publication. [In Persian]

Storey, K., \& Hamilton, L. C. (2004). Planning for the Impacts of Megaprojects (pp. 281-302). Springer Netherlands.

Taghvaee, M. \& Safarabadi, A. (2013). Sustainable urban development and the factors affecting it (Case study: Kermanshah city). Journal of Urban Sociology Studies, 6(2), 1-22. [In Persian] 